Gut, 1962, 3, 211

\title{
The augmented histamine test in the differential diagnosis between ulcer and cancer of the stomach
}

\author{
KAJ FISCHER MANN AND K. H. KøSTER \\ From the Surgical Department A, Bispebjerg Hospital, Copenhagen, Denmark
}

EDITORIAL SYNOPSIS The maximum gastric acidity has been studied using the augmented histamine test in patients with gastric ulcer, with ulcers in the body of the stomach, with pre-pyloric ulcers, and in patients with gastric carcinoma. The results have not enabled a clear distinction to be made between simple and malignant ulcers.

The differential diagnosis between ulcer and cancer of the stomach is based on the history of the disease, the physical examination of the patient, stomach radiographs, gastroscopy, and exfoliative cytology.

Tests of gastric function have played a minor role in diagnosis. It is generally assumed that patients with gastric cancer have achlorhydria or a very low output of gastric acid but it has also been assumed that many apparently healthy people in the 'cancer age', and even patients with stomach ulcers, may have achlorhydria (Vanzant, Alvarez, Eusterman, Dunn, and Berkson, 1932; Barrett, 1946; State, Varco, and Wangensteen, 1947; Heffernon, Kiefer, and Tracey, 1949; Stewart, 1955; Turner, Dockerty, Priestley, and Comfort, 1957; Comfort, Priestley, Dockerty, Weber, Gage, Solis, and Epperson, 1957) when examined by a test meal or after the injection of $0.5 \mathrm{mg}$. of histamine. Gastric function tests were much improved when Kay's augmented histamine test was introduced (1953). This test reflects the maximum secretory power of the gastric mucosa, which depends on the number of parietal cells in the stomach (Card and Marks, 1960). When the augmented histamine test is used only few cases of achlorhydria are found, and achlorhydria must then be regarded as a most important sign which makes Addisonian anaemia or gastric cancer the most likely diagnosis.

Hirschowitz, London, and Wiggins (1957) used the augmented histamine test in 31 patients with gastric lesions. In 16 patients with gastric ulcer the maximum acidity of the gastric juice was always more than $80 \mathrm{mEq} . \mathrm{H}^{+} / 1$, and the chloride concentration more than $135 \mathrm{mEq}$. $\mathrm{Cl}^{-} / 1$. Fifteen patients with cancer of the stomach had concentrations of $\mathrm{H}^{+}$and $\mathrm{Cl}^{-}$which were constantly lower than 90 and $140 \mathrm{mEq} . / 1$. respectively. Using the combined figures for acid and chloride concentrations (Fig. 1) from several samples from each patient Hirschowitz et al. were able to distinguish quite clearly between ulcer and cancer in this series of 31 patients.

Our report describes the results of the augmented histamine test in a larger series of patients with gastric ulcer or gastric cancer.

\section{PATIENTS}

From January 1958 to July 1961348 patients with gastric ulcer and 128 patients with stomach cancer were treated in Surgical Department A, Bispebjerg Hospital, Copenhagen. Thirty-one patients with ulcers and 10 with cancer were not operated upon for a variety of reasons, and are not included in this study. Eighty-one patients with gastric ulcers were operated upon without previous function tests, the majority having emergency operations for bleeding ulcer. Nine with gastric cancer escaped a preoperative test because of bleeding or stenosis which prevented the passing or placing of gastric tubes. This study is, therefore, based on 236 patients with gastric ulcer and 109 patients with cancer, examined by the augmented histamine test and subsequently operated upon. The diagnosis was histologically confirmed in all cases.

The patients with gastric ulcers were divided into two groups, those with ulcers of the corpus and those with prepyloric ulcers. Prepyloric ulcers are located within the gastric antrum, an arbitrary limit being set at $5 \mathrm{~cm}$. from the pylorus.

The age and sex distribution in the three groups of patients (Table I) shows that the majority of ulcer patients are 10 to 20 years younger than the cancer patients. 


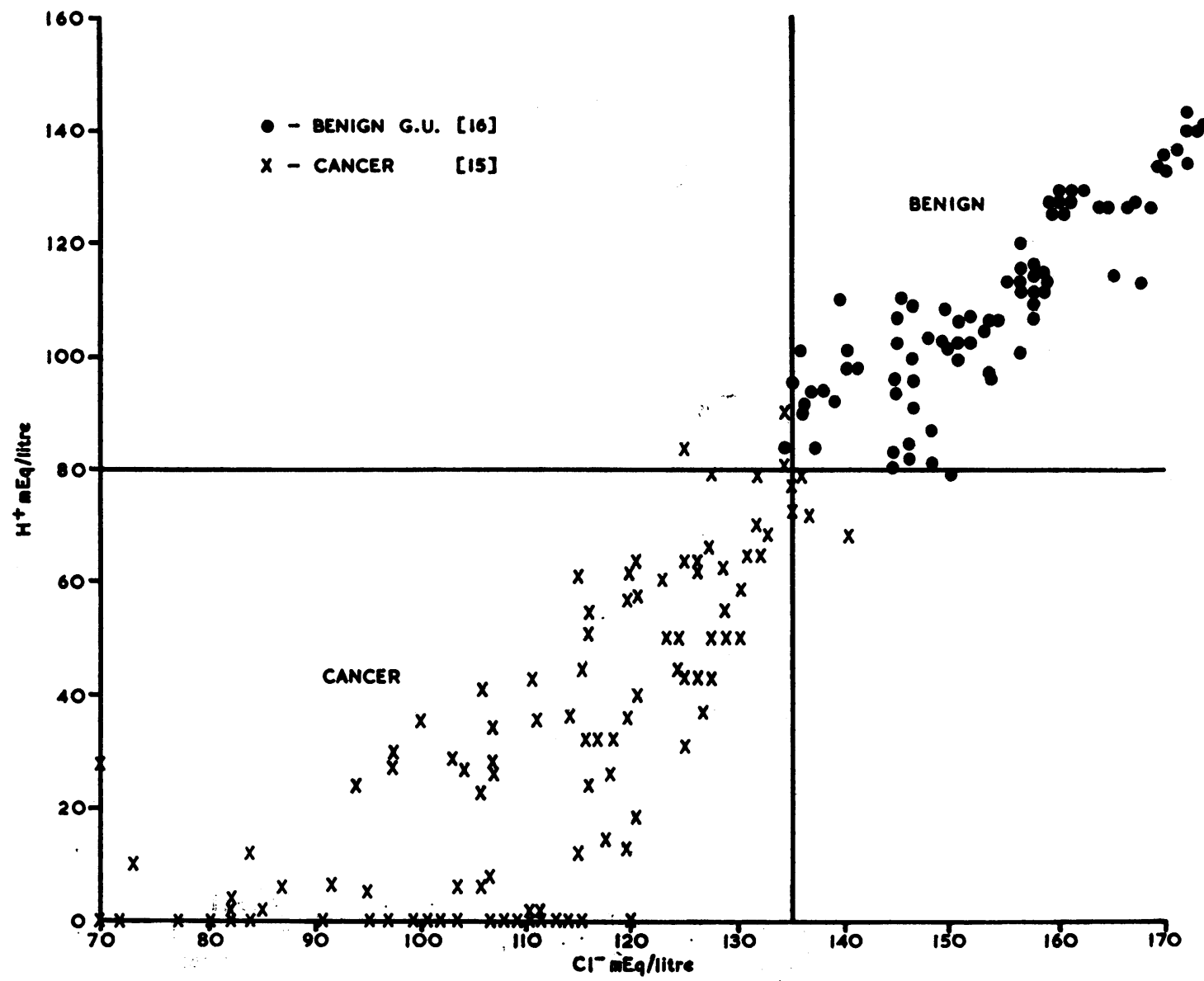

FIG. 1. The maximum gastric secretory response in 15 patients with cancer and 16 with gastric ulcer (Hirschowitz, London, and Wiggins, 1957).

TABLE I

AGE AND SEX OF 345 PATIENTS WITH STOMACH ULCER AND CANCER

\begin{tabular}{|c|c|c|c|c|c|c|c|c|}
\hline Age $(y r)$. & $20-29$ & $30-39$ & $40-49$ & $50-59$ & $60-69$ & $70-79$ & $>80$ & Total \\
\hline $\begin{array}{l}\text { Corpus ulcer } \\
\text { Male } \\
\text { Female }\end{array}$ & $\begin{array}{l}2 \\
1\end{array}$ & $\begin{array}{l}3 \\
3\end{array}$ & $\begin{array}{r}8 \\
20\end{array}$ & $\begin{array}{l}25 \\
19\end{array}$ & $\begin{array}{l}15 \\
21\end{array}$ & $\begin{array}{r}14 \\
8\end{array}$ & $\begin{array}{l}\mathbf{0} \\
\mathbf{3}\end{array}$ & $\begin{array}{l}67 \\
75\end{array}$ \\
\hline Total & 3 & 6 & 28 & 44 & 36 & 22 & 3 & 142 \\
\hline $\begin{array}{l}\text { Prepyloric ulcer } \\
\text { Male } \\
\text { Female }\end{array}$ & $\begin{array}{l}\mathbf{0} \\
\mathbf{0}\end{array}$ & $\begin{array}{l}4 \\
3\end{array}$ & $\begin{array}{l}14 \\
14\end{array}$ & $\begin{array}{l}16 \\
14\end{array}$ & $\begin{array}{r}17 \\
4\end{array}$ & $\begin{array}{l}7 \\
1\end{array}$ & $\begin{array}{l}\mathbf{0} \\
\mathbf{0}\end{array}$ & $\begin{array}{l}58 \\
36\end{array}$ \\
\hline Total & 0 & 7 & 28 & 30 & 21 & 8 & 0 & 94 \\
\hline $\begin{array}{l}\text { Gastric cancer } \\
\text { Male } \\
\text { Female }\end{array}$ & $\begin{array}{l}\mathbf{0} \\
\mathbf{0}\end{array}$ & $\begin{array}{l}\mathbf{0} \\
\mathbf{0}\end{array}$ & $\begin{array}{l}4 \\
3\end{array}$ & $\begin{array}{r}13 \\
3\end{array}$ & $\begin{array}{l}17 \\
15\end{array}$ & $\begin{array}{l}25 \\
21\end{array}$ & $\begin{array}{l}5 \\
3\end{array}$ & $\begin{array}{l}64 \\
45\end{array}$ \\
\hline Total & 0 & 0 & 7 & 16 & 32 & 46 & 8 & 109 \\
\hline
\end{tabular}




\section{METHODS}

In 232 patients, examined between 1958 and 1960, the augmented histamine test was performed as described by Hirschowitz et al. (1957). A continuous infusion of histamine $(5.5 \mathrm{mg}$. histamine diphosphate, corresponding to $2 \mathrm{mg}$. histamine base, in $1,000 \mathrm{ml}$. physiological saline, to which had been added $20 \mathrm{mg}$. mepyramine maleate) was given at the rate of 100 drops per minute. Thus the patient had 10 gamma of histamine per minute. An increase to 14 gamma per minute did not increase the volume nor the hydrochloric acid concentration in the gastric juice (Køster and Thorsøe, 1960). The stomach tube was placed at the greater curvature opposite the angulus, the position of the tube being controlled radiologically. Suction was provided by an electric pump at a negative pressure of $50 \mathrm{~mm}$. $\mathbf{H g}$, frequently interrupted, and completed by hand suction with a syringe.

The acidity of the gastric juice was measured by electrometric titration to $p \mathrm{H} 3 \cdot 3$, the same end-point as chosen by Hirschowitz et al., and the chloride concentration by Brun's modification of Schales and Schales' method.

One hundred and thirteen patients (1960-61) were examined by Kay's original technique (1953) in which 50 to $100 \mathrm{mg}$. of mepyramine maleate was injected intramuscularly and 30 minutes later $0.04 \mathrm{mg} . / \mathrm{kg}$. of histamine was given subcutaneously. Gastric juice was aspirated and titrated as described above.

Kay's technique and Hirschowitz' modification of it gave essentially the same results when both tests were tried in the same patient, a maximum activation of the secretory capacity. In all patients examined the maximum acidity (mEq. $\mathrm{H}^{+} / \mathrm{l}$.) and the acid output (mEq. $\mathrm{H}^{+}$per hour) were determined. In the 232 patients examined by the Hirschowitz modification the chloride concentration was also determined, and the maximum value (mEq. $\mathrm{Cl}^{-} / \mathrm{l}$.) is reported.

\section{RESULTS}

In each of the three groups of patients the maximum acidity (mEq. $\mathrm{H}^{+} / \mathrm{l}$.) for each patient is plotted against the patient's age. In cases where no free acid was produced, the lowest $p H$ attained is shown in the diagram below the zero line for acidity.

GASTRIC CORPUS ULCER One hundred and fortytwo patients were examined and operated upon. At the augmented histamine test 42 patients $(30 \%)$ attained a maximum gastric acidity of $80 \mathrm{mEq}$. $\mathrm{H}^{+} / 1$. or more. Thirty-one patients $(22 \%)$ produced $20 \mathrm{mEq}$. $\mathrm{H}^{+} / \mathrm{l}$. per hour or more (Fig. 2). The chloride concentration reached $135 \mathrm{mEq}$. $\mathrm{Cl}^{-} / 1$. in 56 of $93(60 \%)$ patients examined (Fig. 3). Three patients did not produce any free hydrochloric acid.

Case 1 A 58-year-old man (No. 1652), had a three months' history. On the augmented histamine test the $p \mathrm{H}$ fell from $8 \cdot 1$ to $6 \cdot 1$ and chlorides rose to $80 \mathrm{mEq} . \mathrm{Cl}^{-}$ per litre. An insulin test showed achlorhydria. An ulcer

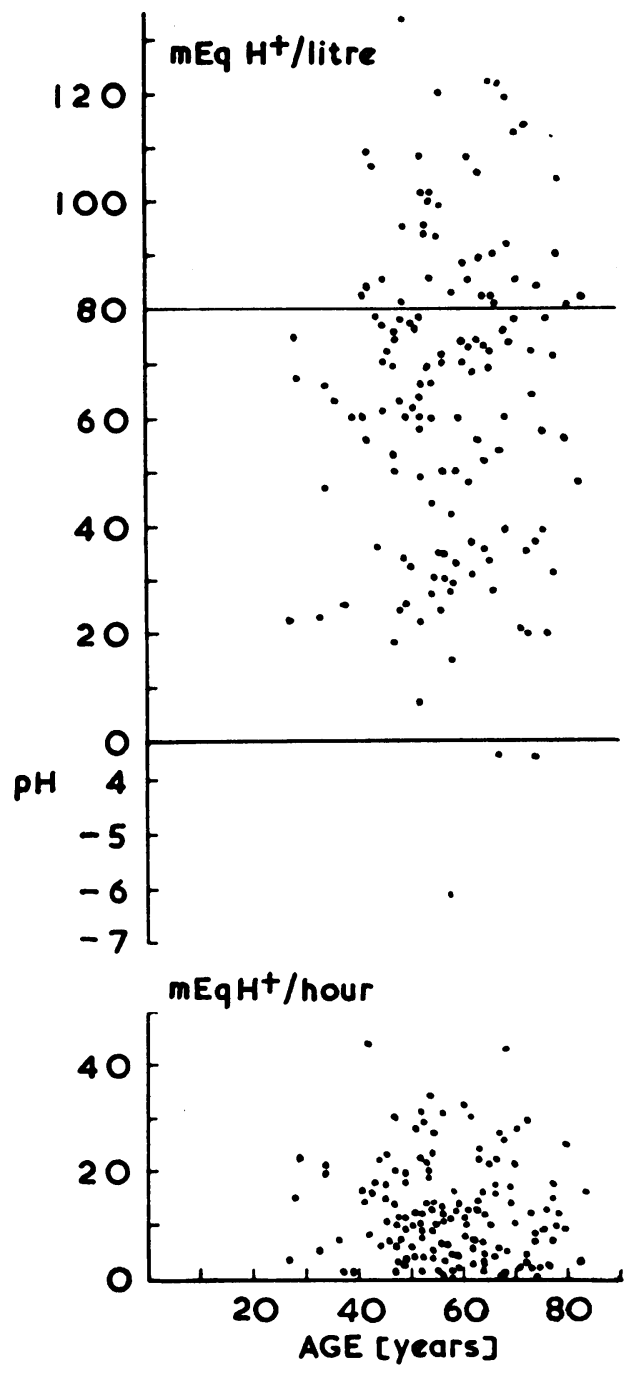

FIG. 2. Augmented histamine test in 142 patients with gastric (corpus) ulcer. Top: The maximum acidity in each case during the test. Bottom: The hydrochloric acid output per hour.

of the cardia $(50 \times 50 \mathrm{~mm}$.) was removed by an upper partial gastrectomy. Serial sections showed no sign of malignancy and biopsies from the stomach mucosa showed extensive gastritis and metaplasia with a few parietal cells.

Case 2 A 74-year-old man (No. 4190), had a four months' history. At the augmented histamine test the $p \mathrm{H}$ fell from $5 \cdot 1$ to $3 \cdot 7$. An ulcer of the cardia $(30 \times 25 \mathrm{~mm}$.) was removed by an upper partial gastrectomy. Histologically the picture was that of periarteritis nodosa, also present in other organs, moderate gastritis, metaplasia, and some parietal cells.

Case 3 A 67-year-old man (No. 5619 A), for many years an alcoholic, had a history of one month. On the 


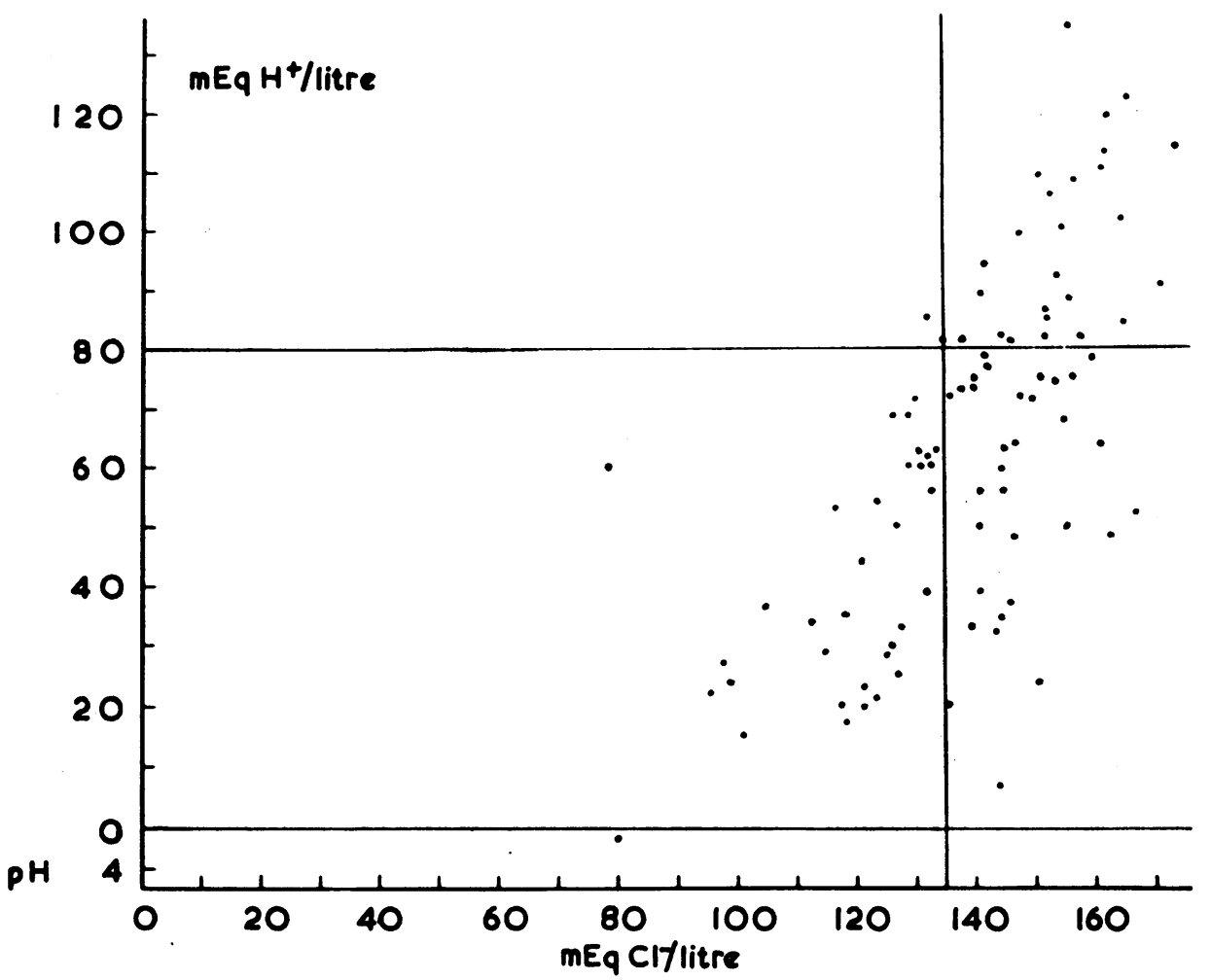

FIG. 3. Augmented histamine test in 93 patients with gastric (corpus) ulcer showing combined plot of the maximum concentrations of $\mathrm{H}^{+}$and $\mathrm{Cl}^{-}$in each patient. Limits of $\mathrm{H}^{+}$at $80 \mathrm{mEq} . / \mathrm{l}$. and of $\mathrm{Cl}^{-}$at $135 \mathrm{mEq} . / \mathrm{l}$. as in Fig. 1.

augmented histamine test the $p \mathrm{H}$ fell from 3.8 to 3.6 . An ulcer $(25 \times 40 \mathrm{~mm}$. $)$ low on the lesser curvature was removed by a Billroth I operation. Histologically the ulcer showed no malignancy but atrophic gastritis without parietal cells. Moderate portal hypertension was found and a liver biopsy showed steatosis.

PREPYLORIC ULCERS Prepyloric gastric ulcers were found in 94 patients, of whom $55(58.5 \%)$ attained a maximum acidity of $80 \mathrm{mEq} . \mathrm{H}^{+}$per litre. Fortyfive patients $(48 \%)$ produced $20 \mathrm{mEq}$. $\mathrm{H}^{+}$per hour or more (Fig. 4). The chloride concentration reached $135 \mathrm{mEq} . / 1$. in 49 of 70 examined patients (70\%) (Fig. 5).

One patient produced no free acid. He was a man aged 61 years (No. 5769), with a 10 months' history of illness. On the augmented histamine test the $p \mathrm{H}$ fell from 8.3 to 3.7 and chlorides rose from 58 to $78 \mathrm{mEq}$. per litre. A prepyloric ulcer $(30 \times 5 \mathrm{~mm}$. $)$ was removed by a Billroth I gastrectomy. Histologically there was no malignancy. Many parietal cells were found in biopsies from the fundus.

CANCER OF THE STOMACH One hundred and nine patients were examined by the augmented histamine test and later operated upon for this condition. Eight $(7 \cdot 3 \%)$ were able to produce gastric juice containing $80 \mathrm{mEq} . \mathrm{H}^{+}$or more per litre. Sixty patients $(55 \%)$ did not secrete any free acid, and of those 20 had anacidity as the $p \mathrm{H}$ was above seven. Four patients $(3.7 \%)$ produced $20 \mathrm{mEq}$. $\mathrm{H}^{+}$or more per hour (Fig. 6). The chloride concentration reached $135 \mathrm{mEq} . \mathrm{Cl}^{-} / 1$. in 17 patients $(25 \%)$ of 69 examined (Fig. 7). The case histories of the eight patients producing gastric juice of high acidity are summarized in Table II. Characteristically, these eight patients all had radical partial gastrectomies performed.

\section{DIFFERENTIAL DIAGNOSIS BETWEEN ULCER AND CANCER}

The highest concentrations of free $\mathrm{H}^{+}$and total $\mathrm{Cl}^{-}$ after the maximum histamine test in 232 patients were plotted showing $\mathrm{mEq} . \mathrm{H}^{+}$per litre on the ordinate and mEq. $\mathrm{Cl}^{-}$on the abscissa. Samples with achlorhydria are represented below zero by the lowest $p \mathrm{H}$ attained during the test. One area of the diagram is defined by the limits of $80 \mathrm{mEq} . \mathrm{H}^{+}$and 

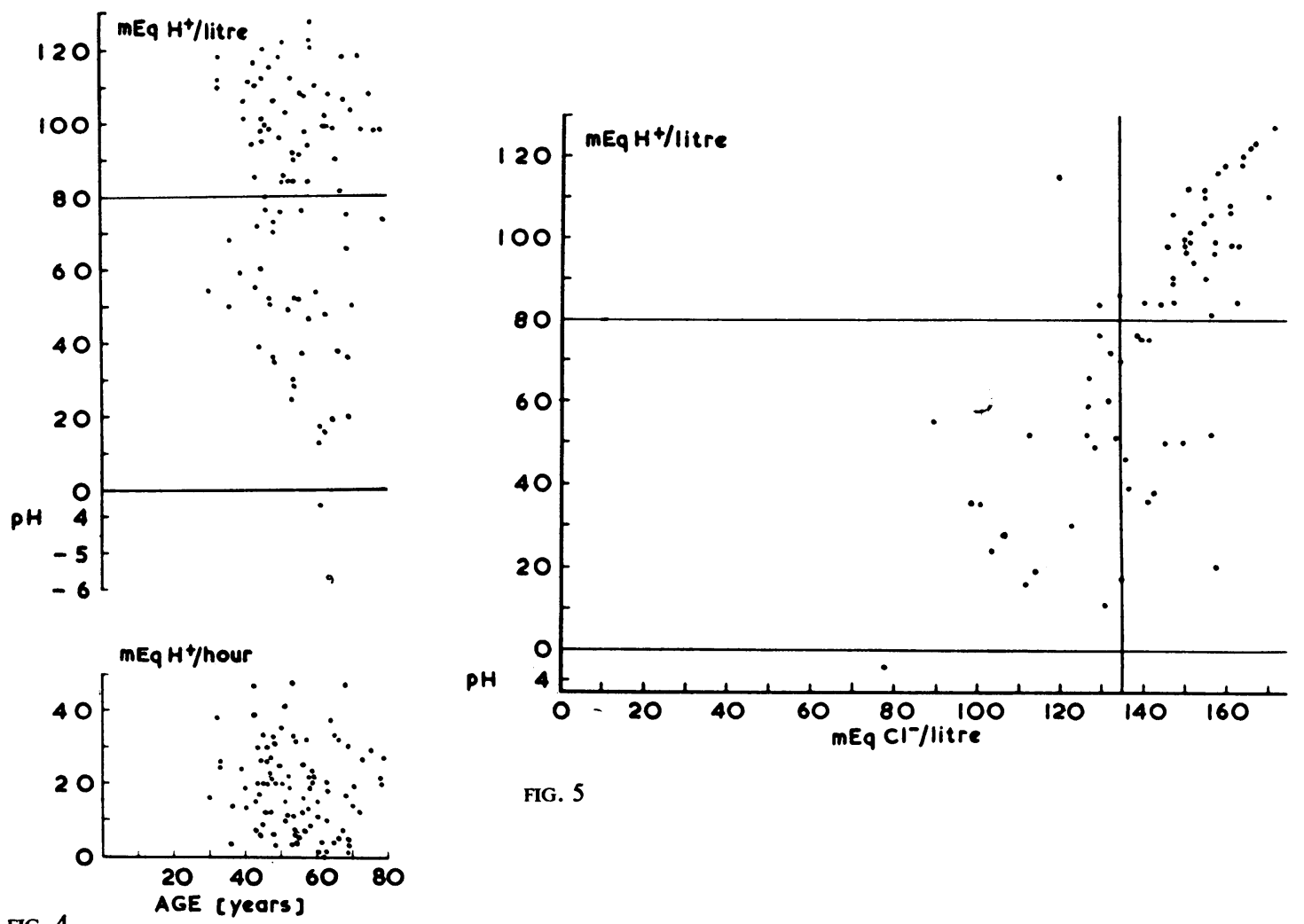

FIG. 5

FIG. 4

FIG. 4. Augmented histamine test in 94 patients with prepyloric ulcer. Top: The maximum acidity in each case during the test. Bottom: The hydrochloric acid output per hour.

FIG. 5. Augmented histamine test in 70 patients with prepyloric ulcer showing the combined plot of the maximum concentrations of $\mathrm{H}^{+}$and $\mathrm{Cl}^{-}$in each patient. Limits of $\mathrm{H}^{+}$at $80 \mathrm{mEq} . / \mathrm{l}$. and of $\mathrm{Cl}^{-}$at $135 \mathrm{mEq} . / \mathrm{l}$. as in Fig. 1 .

$135 \mathrm{mEq} . \mathrm{Cl}^{-}$per litre, and Hirschowitz et al. found that all samples from cancer patients fell in the area situated below these combined limits. For practical reasons the results for patients with corpus ulcers, prepyloric ulcers, and cancer are shown separately (Fig. 3 to 7).

ULCER OF THE CORPUS Ninety-three patients were examined: in $28(30 \%)$ the combined concentrations of free $\mathrm{H}^{+}$total $\mathrm{Cl}^{-}$fell above the combined limits (Fig. 3) in the 'benign' area but in $34(37 \%)$ they fell entirely in the 'cancer' area.

PREPYLORIC ULCER Of 70 patients, in $20(28.5 \%)$ concentrations fell below the combined limits, whereas $38(54 \%)$ produced gastric juice of a higher acidity (Fig. 5).
GASTRIC CANCER Sixty-nine patients were examined: in $65(94 \%)$ concentrations fell below the combined limits in the 'cancer' area, and four patients $(6 \%)$ produced $80 \mathrm{mEq}$. $\mathrm{H}^{+}$per litre or more (Fig. 7).

\section{DISCUSSION}

In this series of investigations we have not been able to distinguish clearly between ulcer and cancer of the stomach by means of the augmented histamine test. Thus we cannot fully confirm the results obtained by Hirschowitz et al. (1957). The comparatively low output of acid in many patients with gastric ulcer in the present series constitutes a major divergence between our results and those of Hirschowitz et al. One hundred and thirty-five 

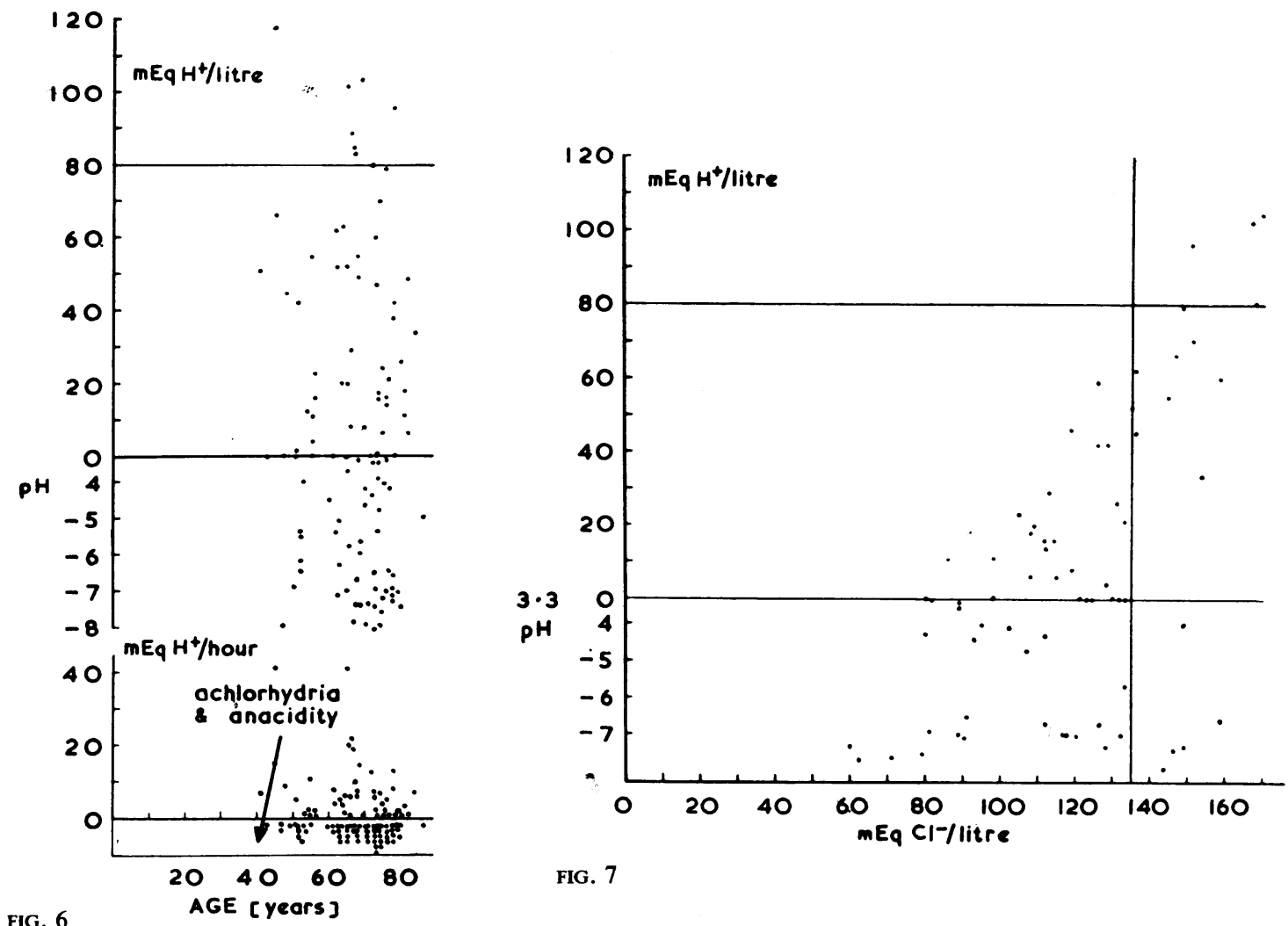

FIG. 6

AGE [years]

FIG. 7

FIG. 6. Augmented histamine test in 109 patients with gastric cancer. Top: The maximum acidity in each case during the test. Bottom: The hydrochloric acid output per hour.

FIG. 7. Augmented histamine test in 69 patients with gastric cancer showing the combined plot of the maximum concentrations of $\mathrm{H}^{+}$and $\mathrm{Cl}^{-}$in each patient. Limits of $\mathrm{H}^{+}$at $80 \mathrm{mEq} . / \mathrm{l}$. and of $\mathrm{Cl}^{-}$at $135 \mathrm{mEq} . / \mathrm{l}$. as in Fig. 1 .

patients, or $57 \%$ of all the ulcer patients, produced less than $80 \mathrm{mEq} . \mathrm{H}^{+} / 1$. after histamine stimulation, and four did not produce any free acid at all. But even those four showed some slight acid secretory activity, as the $p \mathrm{H}$ of the aspirated gastric juice dropped by 0.2 to 4.6 in one hour after the injection of histamine (Table III). Thus, there were no patients with ulcer in whom secretion of acid could not be demonstrated to some degree. Our findings are in agreement with those of Card and Sircus (1958).

The resected stomachs and biopsies from the fundus were examined histologically. Gastritis and metaplasia were commonly associated with gastric ulcer, and would account for the low acidity found in many cases. Furthermore, the chronic and atrophic gastritis, which is seen in the presence of gastric, and to a lesser extent of prepyloric, ulcers (Ball and James, 1961) is indistinguishable from that seen in carcinoma of the stomach, an impression which coincides with the observations of Guiss and Stewart (1948), Morson (1955b), and Joske, Finckh, and Wood (1955).

A less prominent cause of divergence is the high acidity found in certain patients with stomach cancer (Table II). Some of these results are difficult to explain, as the patients had extensive cancers and pronounced gastritis in the examined parts of the gastric mucosa. But others had lesions which by clinical examination, radiographs, gastroscopy, and even at operation were called ulcers. Histology only revealed a small but unmistakable invading cancer in 
TABLE II

Eight Patients With gastric CANCER PROducing $80 \mathrm{mEq} . / 1 . \mathrm{H}^{+}$OR MORE

\begin{tabular}{|c|c|c|c|c|c|c|c|c|c|c|c|c|}
\hline \multirow[t]{2}{*}{ No. } & \multirow[t]{2}{*}{ Sex } & \multirow{2}{*}{$\begin{array}{l}\text { Age } \\
\text { (yr.) }\end{array}$} & \multirow{2}{*}{$\begin{array}{l}\text { History } \\
\text { (yr.) }\end{array}$} & \multicolumn{3}{|c|}{$\begin{array}{l}\text { Augmented Histamine } \\
\text { Test }\end{array}$} & \multicolumn{3}{|c|}{ Diagnosis } & \multirow{2}{*}{$\begin{array}{l}\text { Size of } \\
\text { Tumour } \\
\text { or Ulcer } \\
\text { (mm.) }\end{array}$} & \multirow{2}{*}{$\begin{array}{l}\text { Locali- } \\
\text { zation }\end{array}$} & \multirow[t]{2}{*}{ Histology } \\
\hline & & & & $H^{+} / l$. & $H^{+} / h r$ & $C l-l l$. & $\begin{array}{l}\text { Radio- } \\
\text { graph }\end{array}$ & Clinical & $\begin{array}{l}\text { At } O p- \\
\text { eration }\end{array}$ & & & \\
\hline $\begin{array}{r}796 \\
1676 \\
1745 \\
3607 \\
5925 \\
6580 \\
6665 \\
7484\end{array}$ & $\begin{array}{l}\mathbf{M} \\
\mathbf{F} \\
\mathbf{M} \\
\mathbf{F} \\
\mathbf{M} \\
\mathbf{M} \\
\mathbf{M} \\
\mathbf{M}\end{array}$ & $\begin{array}{l}78 \\
69 \\
70 \\
64 \\
66 \\
44 \\
66 \\
65\end{array}$ & $\begin{array}{l}1 / 12 \\
11 \\
16 \\
1 \frac{1}{2} \\
1 \\
1 \frac{1}{2} \\
6 \\
16\end{array}$ & $\begin{array}{r}96 \\
104 \\
80 \\
102 \\
83 \\
118 \\
85 \\
89\end{array}$ & $\begin{array}{l}13 \\
15 \\
13 \\
41 \\
19 \\
42 \\
22 \\
20\end{array}$ & $\begin{array}{l}151 \\
170 \\
168 \\
167 \\
- \\
- \\
-\end{array}$ & $\begin{array}{l}\text { Cancer } \\
\text { Cancer } \\
\text { Ulcer } \\
\text { Cancer } \\
\text { Ulcer } \\
\text { Cancer } \\
\text { Ulcer } \\
\text { Ulcer }\end{array}$ & $\begin{array}{l}\text { Cancer } \\
\text { Cancer } \\
\text { Cancer } \\
\text { Ulcer } \\
\text { Ulcer } \\
\text { Ulcer } \\
\text { Ulcer } \\
\text { Ulcer }\end{array}$ & $\begin{array}{l}\text { Cancer } \\
\text { Cancer } \\
\text { Ulcer } \\
\text { Cancer } \\
\text { Ulcer } \\
\text { Cancer } \\
\text { Cancer } \\
\text { Cancer }\end{array}$ & $\begin{array}{l}20 \times 20 \\
40 \times 50 \\
25 \times 30 \\
55 \times 50 \\
10 \times 10 \\
40 \times 15 \\
25 \times 25 \\
40 \times 40\end{array}$ & $\begin{array}{l}1 \\
1 \\
1 \\
2 \\
2 \\
2 \\
2 \\
2\end{array}$ & $\begin{array}{l}\text { Chronic ulcer with cancer } \\
\text { Chronic ulcer with cancer } \\
\text { Chronic ulcer with cancer } \\
\text { Adenocarcinoma } \\
\text { Chronic ulcer with cancer } \\
\text { Adenocarcinoma } \\
\text { Carcinoma, solid, anaplastic } \\
\text { Chronic ulcer with cancer }\end{array}$ \\
\hline
\end{tabular}

TABLE III

FOUR PATIENTS WITH GASTRIC OR PREPYLORIC ULCER NOT PRODUCING FREE ACID

\begin{tabular}{|c|c|c|c|c|c|c|}
\hline \multicolumn{3}{|c|}{ Stomach Ulcer in 4 Male Patients } & \multirow{2}{*}{$\begin{array}{l}\text { Parietal Cells in } \\
\text { Biopsy from Fundus }\end{array}$} & \multicolumn{2}{|l|}{ Lowest pH } & \multirow[t]{2}{*}{ Drop } \\
\hline No. & Age & Site & & Before Histamine & After Histamine & \\
\hline $\begin{array}{l}1652 \\
4190 \\
5619 A \\
5769\end{array}$ & $\begin{array}{l}58 \\
74 \\
67 \\
61\end{array}$ & $\begin{array}{l}\text { Corpus } \\
\text { Corpus } \\
\text { Corpus } \\
\text { Prepylorus }\end{array}$ & $\begin{array}{l}\text { Some } \\
\text { Some } \\
\text { None } \\
\text { Many }\end{array}$ & $\begin{array}{l}8 \cdot 1 \\
5 \cdot 1 \\
3 \cdot 8 \\
8 \cdot 3\end{array}$ & $\begin{array}{l}6 \cdot 1 \\
3 \cdot 7 \\
3 \cdot 6 \\
3 \cdot 7\end{array}$ & $\begin{array}{l}2 \cdot 0 \\
1.4 \\
0 \cdot 2 \\
4 \cdot 6\end{array}$ \\
\hline
\end{tabular}

a typical chronic ulcer. Of the 109 patients with cancer, $49(45 \%)$ produced free hydrochloric acid by the augmented histamine test, while another 23 patients $(21 \%)$ made certain small amounts of acid, which reduced the $p \mathrm{H}$ of the stomach contents to somewhere between 3.3 and 6 . The augmented histamine test thus seems to provoke gastric acid secretion in many more patients with stomach cancer than did previous methods of activation.

Swynnerton and Truelove (1951), Björkenheim (1952), and Shahon, Horowitz, and Kelley (1956) found between 22 and $27 \%$ of patients with gastric cancer capable of acid secretion. Anthun (1952) found close to $40 \%$, and the figure of $49 \%$, cited by Pack (1953) for a series of operable cases, is the nearest to our findings.

Another factor which contributes to the discrepancies is the selection of patients for study.
The patients of Hirschowitz et al. had either small ulcers which healed completely while under observation, and only three required operation, or they had advanced cancers, 10 being inoperable. This would account, at least partly, for the wide difference in gastric acid secretion in their ulcer and cancer patients and made the complete distinction possible. The patients reported here were mostly referred from the medical departments for operation. This implies that ulcer patients have had some kind of medical treatment, which failed to cure them, and that patients with stomach cancers were not obviously inoperable. Thus, the patients examined by Hirschowitz et al. and by us are not strictly comparable.

As chronic atrophic or metaplastic gastritis is a common feature of both ulcer and cancer of the stomach, and as the production of hydrochloric acid

\section{TABLE IV}

PERCENTAGE OF CANCER FOUND AT VARIOUS LEVELS OF GASTRIC ACID SECRETION AFTER AUGMENTED HISTAMINE TEST

$\boldsymbol{E}-\boldsymbol{F}$

0
3
3
94
42
31

$\begin{array}{rr}0 & 20 \\ 1 & 40 \\ 4 & 15 \\ 34 & 26 \\ 55 & 8 \\ 45 & 4\end{array}$

$\begin{array}{rr}20 & 100 \\ 44 & 91 \\ 22 & 68 \\ 154 & 17 \\ 105 & 7 \cdot 6 \\ 80 & 5\end{array}$


is proportional to the number of parietal cells in the stomach mucosa, it seems unlikely that it should be possible to distinguish sharply between ulcer and cancer by means of augmented histamine tests and hydrochloric acid titration. The weight which might be attached to such investigations is illustrated by the calculations in Table IV.

We find, in accordance with Comfort and Butsch (1937), and with the reservations mentioned by Hirschowitz et al., that if the free acid exceeds 80 mEq. $\mathrm{H}^{+}$per litre a lesion of the stomach is almost certainly benign but it must not be ignored that we found $7.6 \%$ which were malignant. And we agree with Card and Sircus (1957) that an acid output of $20 \mathrm{mEq}$. $\mathrm{H}^{+}$per hour can almost certainly be taken to exclude carcinoma, as of 80 patients who produced $20 \mathrm{mEq}$. $\mathrm{H}^{+}$or more, only four had cancer. Sixty-four patients of the 345 examined did not produce any free acid, and of those, $60(94 \%)$ had cancer.

This work was assisted by a grant from the Danish Foundation for the Advancement of Medical Science. The Central Laboratory, Bispebjerg Hospital (director, Dr. P. Lous), performed the titrations and $p \mathrm{H}$ measurements on which the work is based.

\section{REFERENCES}

Anthun, O. (1952). Carcinoma of stomach. Analysis and follow-up of 525 cases. Acta chir. scand., 104, 1-13.

Ball, P. A. J., and James, A. H. (1961). The histological background to gastric ulcer. Lancet, 1, 1365-1367.

Barrett, M. K. (1946). Avenues of approach to gastric-cancer problem. J. nat. Cancer Inst., 7, 127-157.

Björkenheim, G. (1952). Free hydrochloric acid in cancer of stomach. Finska Läk.-Sällsk. Handl., 95, 154-162.

Brun, C. (1949). Microdetermination of chlorides in blood. Nord. Med., 42, 1774-1775.

Card, W. I., and Marks, I. N. (1960). The relationship between the acid output of the stomach following "maximal" histamine stimulation and the parietal cell mass. Clin. Sci., 19, 147-163.
Card., W. I., and Sircus, W. (1957). Gastric acidity. Lancet, 2, 934. (1958). In Modern Trends in Gastroenterology (second. series), ed. F. Avery Jones, p. 186. Butterworth, London.

Comfort, M. W., and Butsch, W. L. (1937). Differential diagnosis of benign and malignant small lesions of stomach; attempt to evaluate statistically various symptoms and laboratory findings. Amer. J. Surg., 35, 515-523.

__ Priestley, J. T., Dockerty, M. B., Weber, H. M., Gage, R. P. Solis, J., and Epperson, D. P. (1957). The small benign and malignant gastric lesion. Surg. Gynec. Obstet., 105, 435-448.

Guiss, L. W., and Stewart, F. W. (1948). Distribution of gastric changes accompanying gastric cancers in various locations. Arch. Surg., 57, 624-632.

Heffernon, E. W., Kiefer, E. D., and Tracey, M. L. (1949). Benign gastric ulcers occurring in the presence of achlorhydria. Report of two cases. New Engl. J. Med., 241, 604-606.

Hirschowitz, B. I., London, J. A., and Wiggins, H. S. (1957). Differential diagnosis of gastric ulcer and cancer by a study of maximally stimulated gastric secretion. J. Lab. clin. Med., 50, 447-454.

Hitchcock, C. R., Sullivan, W. A., and Wangensteen, O. H. (1955). The value of achlorhydria as screening test for gastric cancer; 10-year report. Gastroenterology, 29, 621-632.

Joske, R. A., Finckh, E. S., and Wood, J. J. (1955). Gastric biopsy; study of 1,000 consecutive successful gastric biopsies. Quart. J. med., new series, 24, 269-294.

Kay, A. W. (1953). Effect of large doses of histamine on gastric secretion of hydrochloric acid. An augmented histamine test. Brit. med. J., 2, 77-80.

Køster, K. H., and Thorsøe, H. (1960). Ventrikelsekretionen undersøgt med udvidet histaminprøve. Ugeskr. Laeg., 122, 531-536.

Morson, B. C. (1955a). Intestinal metaplasia of gastric mucosa. Brit. J. Cancer, 9, 365-376.

(1955b). Carcinoma arising from areas of intestinal metaplasia in gastric mucosa. Ibid., 9, 377-385.

Pack, G. T. (1953). Diagnosis of cancer of the stomach. New York med. J., 53, 390-392.

Shahon, D. B., Horowitz, S., and Kelley, W. D. (1956). Cancer of the stomach; an analysis of 1,152 cases. Surgery, 39, 204-221.

State, D., Varco, R. L., and Wangensteen, O. H. (1947). Attempt to identify likely precursors of gastric cancer. J. nat. Cancer Inst., 7, 379-384.

Stewart, M. J. (1955). Ulcer-cancer of the stomach, p. 19. (Macewen Memorial Lecture, 1953.) Jackson, Glasgow.

Swynnerton, B. F., and Truelove, S. C. (1951). Simple gastric ulcer and carcinoma. Brit. med. J., 2, 1243-1246.

Turner, J. C. Jr., Dockerty, M. B., Priestley, J. T., and Comfort, M. W. (1957). A clinicopathologic study of large benign gastric ulcers. Surg. Gynec. Obstet., 104, 746-750.

Vanzant, F. R., Alvarez, W. C., Eusterman, G. B., Dunn, H. L., and Berkson, J. (1932). The normal range of gastric acidity from youth to old age. An analysis of 3,746 records. Arch. intern. Med., 49, 345-359. 